\title{
The Magic of a Toolbox - The Prague School in Theatre Pedagogy: Analysis, Comprehension, Creativity
}

Yana Meerzon

\begin{abstract}
In a Canadian general theatre studies or liberal arts program in which the majority of B.A. students are expected to simultaneously take classes in theatre practice and theory, including acting, directing, design, theatre history and dramaturgy, teaching and learning can be challenging. Often our students approach exercises in text and performance analysis as unnecessary or even as superfluous tasks which a practitioner can do without. The naiveté of this hostile attitude is not surprising, but what is interesting is how a system of structural text and performance analysis, specifically here regarding the category of space, can be used as a pedagogical strategy to wake up the student's imagination and eventually become a tool of the practitioner's creative work. In the following, I will describe how to use the analytical methodologies of drama and performance analysis as developed by Prague School theoreticians as a pedagogical strategy to harness creativity. My case study is a 4th year class - Practice of Dramaturgy - which I have taught at the Department of Theatre, University of Ottawa.
\end{abstract}

\section{Key words}

fictional worlds, dramaturgy of space, Prague School, theatre pedagogy

The paper is an outcome of a research project Divadlo jako syntéza umění: Otakar Zich v kontextu moderní vědy a dnešni potenciál jeho konceptů / Theatre as Synthesis of Arts: Otakar Zich in Context of Modern Science and Actual Potential of His Concepts (GAČR 2016-2018, GA16-20335S). 
One of theatre's most persistent myths is the unbridgeable gap between practice and theory, between doing theatre work and the analysis of these practices. In a Canadian general theatre studies or liberal arts program in which the majority of B.A. students are expected to simultaneously take classes in theatre practice and theory, including acting, directing, design, theatre history, and dramaturgy, teaching and learning can be challenging. Often our students approach exercises in text and performance analysis as unnecessary or even as superfluous tasks which a theatre practitioner can do without. The naiveté of this hostile attitude is not surprising, but what is interesting is how a system of structural text and performance analysis, specifically regarding the category of space, can be used as a pedagogical strategy to wake up the student's imagination and eventually become a tool of the practitioner's creative work. In this article, I will demonstrate how the analytical methodologies of spatial dramaturgy developed by the members of the Prague Linguistic Circle (Prague School) can serve to harness this creativity.

My case study involves a 4th year undergraduate course - Practice of Dramaturgy which I taught for over a decade at the Department of Theatre, University of Ottawa. The objective of this course is two-fold: on the one hand, it aims to introduce theatre students to the fundamentals of dramaturgical research; on the other, it serves as training in playwriting. Over the years, students practiced textual adaptation and focused on developing skills in imagining and constructing theatrical worlds. The analytical categories of space and fictional worlds developed by Prague School theoreticians often served as a springboard for these projects. In the earlier versions of this class, students worked with examples of world literature, using the notion of Eco's 'completely furnished world' (1987). They used material from short stories (e.g. from Kafka, Chekhov, Ray Bradbury) to write one-act plays. In the process, they would acquire dramaturgical skills in character development, conflict building and resolution, as well as suspense. Their task was to create a 2D textual record (theatre script) of a 3D theatre production as it would appear in their imagination. To teach the techniques involved, I used tactics of literary and performance analysis, developmental dramaturgy and acting pedagogy. Textual adaptation was my pedagogical, 'conceptual and practical model for developing [students'] critical and creative skills simultaneously' (MCKINNON 2011: 55). My pedagogy was also influenced by Elinor Fuchs' theory of fictional planets (FUCHS 2000), Linda Hutcheon's work in literary adaptation (HUTCHEON 2006), Vincent Murphy's guide for making theatre adaptations (MURPHY 2013), as well as Susan Jonas' practice of collaborative dramaturgy (JONAS 1996). As a result, I developed my own model for adapting short stories into theatre, a model that heavily relies on Michael Chekhov's strategies for character and plot analysis as well as acting techniques (MEERZON 2015). Recently, however, I have changed my approach. In 2017 and 2019, I asked students to choose a historical figure or event from any time period or geographical region as a point of departure for their exercises in creating counterfactual fictional worlds (DOLEŽEL 1998) of theatre. Instead of writing a full one-act play based on a short story, now students were asked to develop a dramaturgical model for a fictional world reflecting their knowledge and interpretation of the historical period in which they chose to set the proposed fictional action. 


\section{Fictional worlds in literature and theatre}

As early as Aristotle, theatre scholars have theorized how dramatic texts and performances create their fictional worlds, i.e. an illusion of action that takes place elsewhere. According to Aristotle, fictional worlds are created through an imitative act called $m i$ mesis, and thus they must reflect the world we live in, with the events and the characters necessary or probable (ARISTOTLE 1987). According to Lubomír Doležel and other theoreticians of possible worlds semantics, fictional worlds of literature are defined by 'what is possible, impossible, and necessary within its world' (DOLEŽEL 1998: 788). ${ }^{1}$ They are "not imitations or representations of the actual world (realia) but sovereign realms of possibilia; as such, they establish diverse relationships to the actual world, situate themselves at a closer or further distance from reality. They range from realistic worlds closely resembling the actual world to those violating its laws, fantastic worlds' (DOLEŽEL 1998: 788). Fictional worlds in literature 'are products of textual poiesis. By writing a text the author creates a fictional world that had not been available prior to this act' (DOLEŽEL 1998: 789). However, fictional worlds are not constructed only in the realms of written literature, but also through '[oral] mythology and storytelling, painting and sculpting, dance and opera, theatre, cinema and television' (DOLEŽEL 1998: 787). Doležel defines a 'fictional text [as] created by the power of speech act or authentication through different types of authorial and character discourses' (DOLEŽEL 1998: 790).

In theatre, space and actors take on the special role of the authenticators of a fictional world. This act of authentication must be visual, and it must take place in space and action, as well as in the presence or with participation of a live audience. To Keir Elam, the act of authentication in theatre takes place without narratorial guides (ELAM 2002: 101-102). The fictional world is authenticated both by dramatic characters, who make references to it, as well as by the spectator, who makes inferences about the world, i.e. he/she uses the act of witnessing as a mechanism of world-making (ELAM 2002: 101-102). Accordingly, if in written literature it is both the narrative voices and readers who authenticate 'fictional facts', in theatre it is the dramatic characters and spectators who 'must authenticate the world by observing action', thus 'the onstage space, and the events that occur therein, take over the narrator's authority' (GINGRICH 2014: 25).

Building a fictional world of theatre based on a particular historical event or figure takes on specific conditions of authentication. 'Historical texts, constrained by the requirement of truth-valuation, construct historical worlds which are models of the actual world's past' (DOLEŽEL 1998: 792). These worlds include a cast of agents, events and settings that belong to the actual historical events and 'are imaged to

1 The concept of possible worlds has been delineated in many ways, notably in literary theory by Thomas Pavel (1989) and Umberto Eco (2004), but also by the scholars of literature and cognitive studies, such as E. Semino, P. Werth, K. Oatley and others. These influential frameworks complement the fictional worlds theory of Doležel (1998), however it is beyond the scope of this article to develop further connections among these fields. 
be as similar as possible to the actual persons of the past' (DOLEŽEL 1998: 794). However, the worlds of fiction and history remain incomplete epistemologically and ideologically, i.e. they are defined by the factual gaps produced by the author/historian. These gaps stand for both the pragmatic and artistic choices the writer made, including considerations regarding plot and character development as well as availability of documentary material and textual sources (DOLEŽEL 1998: 795). Artistic deviations in the fictional world are justified by putative 'poetic license', which can reveal the artist's ideological, cultural and artistic position. As the result, fictional worlds referenced from history are not distortions or alternative histories, they are its counterfacts (DOLEŽEL 1998: 795). 'Distorted history is history that never happened' - Doležel argues; it is 'a tool of totalitarian ideology for enforcing its image of the past' (DOLEŽEL 1998: 801). Counterfactual history presents 'a thought experiment that changes or eliminates a factor of actual history and thus tests its significance' (DOLEŽEL 1998: 801); 'counterfactual histories are products of imagination' (DOLEŽEL 1998: 802), serving as tools for historiography. In the worlds of counterfactual history, the relationship between an actual historical figure, event or landscape and its fictional representation 'extends across world boundaries, fictional entities and their actual prototypes', all of which are interlinked by a 'transworld identity' (DOLEŽEL 1998: 788).

In my classes on the Practice of Dramaturgy, students create counterfactual fictional worlds of theatre. As their point of departure, they use Elinor Fuchs' article 'EF's Visit to a Small Planet: Some Questions to Ask a Play' (2004) and use Fuchs' six analytical categories as a set of creative tools to transform an existing theatre play into new performative environments.

Similarly to the literary theory of fictional worlds, Fuchs emphasizes spatial/temporal aspects of reception and the reader/creator's work of vision as experiential and embodied dynamics in the analysis and creation of a theatre play. Fuchs recognizes the dramatic text not as 'a flat work of literature, not a description in poetry', but as 'another world passing before you in time and space', so 'when you "see" this other world, when you experience its space-time dynamics, its architectonics, then you can figure out the role of language in it' (FUCHS 2004: 6). In her approach, Fuchs relies on the methodologies of structural play analysis 'to forestall the immediate (and crippling) leap to character and normative psychology that underwrites much dramatic criticism' (FUCHS 2004: 5). The six categories of play-analysis she proposes roughly correspond to the six elements of spatial dramaturgy that I have devised for my students: 


\begin{tabular}{|c|c|}
\hline Six categories of play analysis & $\begin{array}{l}\text { Meerzon's Categories of Spatial Dramaturgy based on } \\
\text { Fuchs' model }\end{array}$ \\
\hline $\begin{array}{l}\text { The World of the Play: First } \\
\text { Things First }\end{array}$ & $\begin{array}{l}\text { Spatial/temporal arrangement of the play or its chro- } \\
\text { notope; this can include atmosphere, mood, and music } \\
\text { and / or sound characterizations }\end{array}$ \\
\hline $\begin{array}{l}\text { The Social World of the Play: } \\
\text { A Closer Look }\end{array}$ & $\begin{array}{l}\text { Social/historical parameters of the world, questions of } \\
\text { class, gender, and cultural characteristics that make it }\end{array}$ \\
\hline What Changes? & $\begin{array}{l}\text { Events of the world that bring changes to its spatial/ } \\
\text { temporal and social/historical characteristics }\end{array}$ \\
\hline Don't Forget Yourself & $\begin{array}{l}\text { The author/spectator/receiver's point of view - how } \\
\text { do the changes in the world affect the receiver? }\end{array}$ \\
\hline Theatrical Mirrors & $\begin{array}{l}\text { What potential of theatrical re-incarnation or staging } \\
\text { does this world contain? How open is it for trans-histo- } \\
\text { rical and trans-cultural transpositions? }\end{array}$ \\
\hline The Character Fits the Pattern & $\begin{array}{l}\text { Understanding each character from its functional posi- } \\
\text { tion: i.e. how a certain character fits or does not fit the } \\
\text { patterns of the given world }\end{array}$ \\
\hline
\end{tabular}

Free to choose any artistic media appropriate to their projects, students have used words (dialogue), bodies, images, sound, objects, digital and analog audio-video, as well as film as construction materials. Space became the major focus point in all our discussions, as students identified an ideal performative setting for their work, be it a designated theatre stage and configuration (such as proscenium, thrust, theatre-in-the-round, arena, black-box), or a site-specific or porous performance space (TURNER 2014). Theoretical writings by the Prague School theatre scholars - including Zich's rendering of the dramatic and performance space as a vehicle for the rhythm and atmosphere of the action and its field of energy, Brušák's theory of a dramatic and imaginary action space, and Vodička's contextual and affective concretization - have become indispensable tools to guide and inspire my students' creative thinking. Before I focus on describing and analysing the artistic processes my students have undertaken, I will offer a brief look at the devices of spatial dramaturgy as developed by the leading Prague School theatre theoreticians, both in their analytical and creative dimensions.

\section{On spatial dramaturgy: analytical and creative approaches to fictional world construction in theatre}

In his Aesthetics of Dramatic Art (1931), Otakar Zich outlines his primary strategies of spatial dramaturgy. A technique of play and performance analysis, spatial dramaturgy implies understanding theatre performance as visual art, 'a synthesis of auditory, visual and tactile elements, a feature that distinguishes it from the other arts, which are based on only one or (at best) two senses, such as paintings (visual elements), music 
(auditory elements) or sculpture (visual and tactile elements)' (DRÁBEK 2016: 618). Zich suggests that space in theatre works physically, semiotically and emotionally, i.e. he 'differentiates between what we perceive through our senses and what we imagine' (DRÁBEK 2016: 619), and he distinguishes between 'the theatre space (an actual theatre building), the stage (an empty space built intentionally for theatre productions), the set (real space or materials on stage that represent another space) and finally dramatic space, the imagined (and fictional) place of an action' (DROZD and KAČER 2016: 20). To Zich, the theatre stage is 'a space in which dramatic characters materialize the dramatic action' (ZICH 2016: 50), whereas dramatic space 'originates in time through the gradual changes in the spatial relations between the actor and the stage and between the actors themselves' (MUKǍ̌OVSKÝ 2016: 69). Dramatic space unfolds beyond the actual stage. i.e. it can be extended 'in all directions. This gives rise to the phenomenon referred to as the imaginary stage' (MUKǍ̌OVSKÝ 2016: 70). ${ }^{2}$ Karel Brušák expands on this idea by differentiating between four types of theatre space: a stage or physical architecture of a performance space; a scene or a variable space created by scenery and theatre equipment; an action or fictional space of drama where the action takes place; and, finally, an imaginary action space as formed in the minds of a spectator (BRUŠÁK 2016: 303). Brušák argues that the third space, the action space, consists 'almost entirely of signs originated by the actors, emphasized or completed by signs supplied by sound and lighting. It is the kinetic quality of the action space that gives drama its specific character, yet it does not depend only on its inner tension but also on its confrontation with the spectator' (BRUŠÁK 2016: 305). The action space constitutes 'a field of forces with a considerable kinetic energy. The interplay of these forces results in what is commonly understood as dramatic tension' (BRUŠÁK 2016: 306). This tension is restricted within the time-space continuum of the play, so the limitation to the spread and the duration of space is the leading characteristic of dramatic or action space (BRUŠÁK 2016: 306). In this way, Brušák continues to develop Zich's idea that spatial position of the actors and objects on stage creates visual representation of a dramatic conflict: 'Through these visible spatial relations between individual characters (close to or distant from one another, and so on) as well as between the characters and the stage (downstage, upstage, stage left, and so on), the psychological relationships between dramatic characters are expressed visually' (ZICH 2016: 54). These spatial/temporal configurations are characterized by rhythmical juxtaposition of the on-stage bodies,

2 The imaginary action space is a kind of echoing to the dramatic space, but it exists only in the imagination of a spectator and its elements are different to those of the dramatic space (BRUŠÁK 2016: 306). This space originates on stage through the actions of actors and other material and indexical signs (BRUŠÁK 2016: 307). Similarly to painting, it uses 'polysemantic signifiers' (BRUŠÁK 2016: 316). The imaginary action space also bears a narrative function, as it provides a time-space continuum of the action, from which it emerges at the top of the story and to which it retreats at the end of it (BRUŠÁK 2016: 317). Brušák categorically argues that the imaginary action space cannot be located in the space of the audience. To him, theatregoers 'must remain the addressees not the originators of the signs' (BRUŠÁK 2016: 310), thus the action space and the audience space cannot be shared and must remain autonomous to each other (BRUŠÁK 2016: 306). This theoretical postulate has been challenged by participatory and immersive theatre, which I refer to briefly at the end of this article. 
which creates invisible playing areas allotted between and among the performers, the space and the objects. Characterized by 'the visible rhythm of the changing stage, visually expressing the dramatic rhythm of the action'; these invisible playing areas also serve as 'transitional point[s] between what we have seen before and what we shall see after it' (ZICH 2016: 55). Zich calls this energy distribution in space a force field (ZICH 2016: 56), a concept which defines the architectural, the theatrical, and the dramatic places of performance:

Every piece of architecture is also a dynamic field, a network of lines of force. Here, however, it is a case of mechanical forces, of the weight of matter manifesting itself as compression and tension, and of the firmness and flexibility of the material resisting this. These forces and counterforces are in complete balance [...] the force field of the theatre stage is mobile, in a constant state of change and flow, and it is first of all a field of psychological, not mechanical, forces. [...] The forces we sense here are not real, actual, but only imagined, symbolic. (ZICH 2016: 56)

The director's role is to recognize the existence of such a force field in the source material, especially when working with a pre-existing dramatic play, and to reveal these flows of energy on stage for the audience: 'the dynamic effect of the drama is not only distributed on the stage but is also ordered. This means that it is regulated according to laws in terms of both spatial distribution as well as its development in time. The sole possible basis for this order is the dramatic work itself, conceived as a whole' (ZICH 2016: 56).

To the Prague School theoreticians, the action of the theatre stage has both a logical and emotional impact on the audience. It is not surprising then that their understanding of how spatial dramaturgy works corresponds to more recent readings and applications, including participatory and immersive theatre practices. These new categories of spatial dramaturgy include: (1) architectural space, or a designated theatre building, a found or a site-specific place, indoors or outdoors; (2) theatre stage, or a spatial configuration of the stage space that functions as a setting for the dramatic action to unfold; (3) dramatic space created through the interaction between characters, presented on stage in front of the audience and as a potentially imaginary or 'off-stage' component; (4) stage space as the interaction among performers' bodies and objects; (5) audience space, to which spectators have full physical access and where the work of reception takes place; and (6) performance space - the place for theatre space and audience space to meet, interact, and overlap (adapted from MCAULEY 1999).

In the next section of this article, I describe and examine how the students of my Practice of Dramaturgy class have used the Prague School theories of spatial dramaturgy to create their own counterfactual theatre worlds of history, freely mixing them with more contemporary approaches to space in theatre. 


\section{Conceptualizing counterfactual theatre worlds}

In the class Practice of Dramaturgy, the process of conceptualizing and building a counterfactual theatre world unfolds in five critical and creative steps. The end result is a student-led public presentation of the newly imagined and constructed fictional world. These creative steps include:

Step 1: Field work (dramaturgical research, preparation for creative project)

Step 2: Identifying major dramaturgical elements/ingredients of the chosen fictional world (space, characters, time, storyline)

Step 3: Identifying the major changing point/event/action

Step 4: Presentation of the fictional world

Step 5: Reflection on the process of creating the project

The first step of the project, Field Work, is strictly analytical, as students must take stock of, research and otherwise enhance their own knowledge of the social and cultural environments that make up the historical period they have chosen to work on. At this stage, students use Fuchs' questionnaire to select historical events, landscapes, and figures to be featured in their newly constructed counterfactual worlds. Specifically, they are asked to devote particular attention to Category Four of Fuchs' model: 'Don't Forget Yourself'. Seeking what changes exist or are to come in a fictional world, Fuchs writes:

[a reader/artist must not] forget to ask what changes in you, the imaginer of worlds. Ask, what has this world demanded of me? Does it ask me for pity and fear? Does it ask me to reason? To physically participate in the action on the stage? Does it ask me to interact with other spectators? To leave the theater and take political action? To search my ethical being to the core? Maybe this world means only to entertain me, why not? But how does it make this intention known? (FUCHS 2004: 9)

These questions define the student's role as a primary collector and interpreter of historical information. Methodologically, Fuchs' challenges to practitioners correspond to Felix Vodička's notion of concretization (1975), a process which involves the artist-creator's collection, analysis and creative remodelling of the chosen material. As Drábek describes, this journey is 'both individual (the recipient draws on his or her own individual knowledge and experiences for the interpretation) and cultural and historical (the circumstances of the reception go beyond the individual and interact with larger frames of reference)' (DRÁBEK 2016: 612). A student's work in dramaturgical concretization corresponds to the second step in building the counterfactual world identifying major dramaturgical elements/ingredients of the chosen fictional world. This step consists of a description of the physical and temporal dimensions of the student's fictional worlds as well as creating a storyboard with the proposed action breakdown for a future performance. This storyboard is similar to the panel-layout in a comic 
book, as it indicates both the character development $\operatorname{arc}(\mathrm{s})$ and the audience's journey through the world. A single storyboard can follow (1) fictional plot line or character arc; (2) the audience's journey through the world; and/or (3) a mix of both. This rendering can also help the student imagine potential fictional worlds in spatial/temporal terms. Overall, this exercise enhances skills of imagining or listening to the unborn dramaturgical material and identifying a complete fictional world in yet amorphous and raw historical fabric of the creative project.

The third step in creating a counterfactual fictional world, Identifying the Major Changing Point/Event/Action, consists of the student's recognition and justification of one significant moment of change in the proposed action that can radically re-shape the atmosphere and the rhythm of the fictional world. In classical dramaturgy, this significant moment of change would refer to the climactic point in plot development or a point of no-return in the dramatic action. It can also signify an inciting incident, when the world is shaken, or a point of attack, when a character emerges as a leader of dramatic action (RUSH 2005). To demonstrate how a moment of change alters a spatial/temporal layout of the world, the students are asked to choose a scene that contains this type of change and to reconstruct it using the performative media chosen for their projects. Imagining the potential spatial layout of the fictional world constitutes an important sub-step in this process.

The class Practice of Dramaturgy concludes with the public presentation of student projects and an extended discussion of their process. Their final assignment is Writing a Dramaturgical Report in which students are invited to reflect critically on their creative process in constructing the counterfactual fictional world. In their reflection papers, students are asked to describe and examine all steps of the dramaturgical research and creation they have undertaken during the semester. This final text reflects the students' knowledge of plays, productions and theory related to the practice of documentary theatre and building counterfactual worlds of fiction. Each student is encouraged to respond to these questions: Who is your historical figure and why have you chosen this figure? What research strategies and sources did you use to find out information on this figure? What creative/dramaturgical choices did you make to imagine your fictional world? and What theatrical or other performative media did you decide to work with and why?

\section{Application}

In building their counterfactual fictional worlds in 3D, my students have often opted for immersive theatre practices. They have devoted special attention to audience space, a spatial-temporal lagoon where the feedback loop of aesthetic energies between the stage and the spectators takes place (MCAULEY 1999: 246), and performance space that 'accentuates the individual's response to the performance' (MCAULEY 1999: 248). Audience space is marked by such elements of (un)intentionality as gaps of meaning, personal and historical concretizations, speech acts of walking (DE CERTEAU 
1985), manifestations of heterotopia and panopticon (FOUCAULT 1986), and 'a selfreferential and ever-changing feedback loop' (FISCHER-LICHTE 2008: 38). Performance space facilitates 'the construction of a sense of occasion, or a sense of the group as a collective' (MCAULEY 1999: 249); it capitalizes on the social energy aroused by stage/audience interaction (MCAULEY 1999: 252). Bringing performance space to life is the process of spatializing and temporizing performer/audience interdependence, accomplished through mobilizing spectators or changing the proximity of bodies and objects in space. Using affect, performance space can implicate spectators into the action, thus dynamic and engaged spectatorship can be created.

Constructing fictional worlds of immersive theatre capitalizes on audience participation, with spatial dramaturgy as the methodologies of spectator 'engagement, engrossment, and total immersion similar to video-gaming' (BOUKO 2015: 460). Audience immersion depends on the individuals' willingness and consent to participate in the performative action, while this action offers a passage from a site-specific to site-sympathetic experience, ultimately aiming at empowering a spectator (BOUKO 2015: 461). The artistic directors of the Punchdrunk project Felix Barrett and Maxine Doyle offer an iconic example of immersive theatre practice. These artists have identified spatial dramaturgy as the cornerstone principle in their work (BARRETT and DOYLE 2009: 92). With their London group, Barrett and Doyle use the crescendo of the space (BARRETT and DOYLE 2009: 94) as a leading element, an approach to space which endeavours to maximize the physical, emotional, atmospheric and affectual impact on the audience. Commenting on Punchdrunk's 2007 production of Goethe's Faust, which took place in a 150,000 square foot warehouse in the derelict London neighbourhood of Wapping, Maxine Doyle says:

I remember walking through the space and not really having a sense of what would be where, until we got down to the basement, which was the one space that was suited to hell. It matched beautifully the ideas in some of the final scenes with Gretchen when she's imprisoned [...] we didn't change that space, we talked about curtaining it, we talked about flooding it [...], but ultimately it didn't need anything and all we did was put in some simple rigging, which was invisible, and two black straps to do some very simple aerial work. The atmosphere, the space was a given. (BARRETT and DOYLE 2009: 93)

Further, the creative team 'realized that in the same way that the audience descend down to hell, [...] the show echoed the building, the show was the building' (BARRETT and DOYLE 2009: 94). Space has become instrumental in the work of Punchdrunk (BARRETT and DOYLE 2009: 98). Similarly, thinking creatively through space has become the major strategy of building counterfactual fictional worlds for my students.

To choose some examples, student Catherina Fiorindi (2017) selected the life of Sophie Scholl and the work of the White Rose, a youth resistance movement against the regime of Hitler and Nazi Germany, the raw material of which she used to create a counterfactual world of theatre (see SCHOLL and SÖLLE 1983). Structurally, the project was inspired by theatre director Anne Bogart's concept of 'windows', a 'look at 
a specific theatrical moment through a window of space' (BOGART and GRAY 2015: 213). The 'architecture of a peep show' informs Bogart's windows, so 'each member of a collaborative team views the production from a separate booth and through a different window' (BOGART and GRAY 2015: 213). Fiorindi chose to tell the history of the rise and the fall of the White Rose using the device of performative windows, moving the audience through the stations/windows on their guided journey. Theatre practitioner and teacher Erin Schiebe's 7 Stages of Experience as set in a historical museum became Fiorindi's core concept to 'enhance and individualize guest experience' (SCHIEBE 2014: 101). 'Placed on a visual structure, the 7 Stages of Experience would look similar to the literary Freytag Pyramid, beginning with the informing of an audience, rising to a climax and ending with a definitive conclusion' (SCHIEBE 2014: 101). Fiorindi found two stages of this performative journey - Embark on a Journey and Pay Off - the most useful in building her counterfactual world. Embark on a Journey invites spectators into the world of the experience; it is 'the first-time audience members have the chance to engage relationally to a performance' (SCHIEBE 2014: 103). Fiorindi decided to cast a performer/historical impersonator in the character of Sophie Scholl to act as audience's guide, so the project changed 'from being a self-guided [museum] tour to an actual story telling experience' (SCHIEBE 2014: 8). This decision determined how the Pay Off moment would be brought about as the audience concludes their physical journey through the exhibit. In the final room of the installation, Fiorindi explains, Sophie is no longer narrating the activities, leaving the audience unguided to witness the archival documents and come to their own conclusions regarding the fate of this movement:

The last room is a gallery, full of pictures of the members of the White Rose organization with their names, ages and death dates underneath. As the audience members peruse the room they see Sophie's picture and come to realize that their guide is Sophie Scholl and this is how her story ended. The Pay Off provides closure, but also a communal experience of having the opportunity to learn a story that is not often told and realize the true impact of it. (FIORINDI 2017: 8)

Fiorindi's installation demonstrates the importance of teaching students the skill of imaging a fictional world in its entirety. It shows that the dramatic world need not be represented solely in a dialogue; it can be activated in space, through the work of actor's performance along with audience interactions with all the elements involved. Designing an interactive walking experience, Fiorindi had to imagine both the arc of the character's journey as well as that of the audience, experiences that cannot completely coincide with or repeat each other exactly. The dramaturgy of encounter has become her guiding principle, whereas the layout of objects in space or, rather, their rhythmical position in relation to the movement of the audience, was this fictional world's defining characteristic, with each room carrying its own atmosphere and energy fields: 
I have realized that when creating a [fictional] world it is necessary to be open to all styles and techniques that are available so as to create a project. My project about Sophie Scholl has grown from what could have just been an exposé on the lifetimes of Sophie to an immersive experience that asks the audience to step into her world and watch her life unfold and ultimately come to end. Thanks to the many steps of this process I was also able to come to the realization that it was not just Sophie's journey but also the audience's journey that needed to be carefully crafted and thought out. Thus my project evolved, and Sophie became a guide to the audience to provide them with a deeper understanding of what it meant to be part of the White Rose and of the impact that Sophie and the organization hoped to have. (FIORINDI 2017: 10)

This connection between the world and the audience is often performed in conjunction with the act of walking, as spectators pass through the space of an immersive performance. Moving from one locale or performance station to the next presupposes audience's physical concretization of the imaginary action space (BRUŠÁK 2016: 303) and functions as an element of suspense; whereas the spatial dramaturgy of immersive experience capitalizes on the ambiguity of the imaginary action space and implements the work of spectators in building a performance. It employs audience's kinetic, tactical, and emotional interactions with space, sound, and objects of performance to localize and concretize its imaginary action spaces. Similarly to turning the pages of a picture book, we move through the installations to discover new characters and events, visualizing and embodying the fictional action-board in the trajectories of our own walking. Transitioning from one station/panel to the next, we connect the panels to each other: so walking through the performance serves as a device of fictional world building by the audience. This process of performance building also relies on our deciphering the meaning of each installation by visually experiencing the layout of each space and interacting with it. The audience uses memory and imagination to connect panels to each other and to fill in the narrative gaps left out by the installation. Walking, in other words, functions as the syntax of this narrative structure, i.e. moving through the performance space activates the production. This serves as one of many methodological strategies of performative immersion, an approach which envisages the work of immersive audio-visual installation as a crossover between theatre stage and audience space. This crossover functions as a newly constructed performance space - a place for dramatic action to unfold and for theatregoers to interact.

Another example would be the project of Cullen McGrail. It presents another way of building counterfactual worlds of history in theatre using the devices of spatial dramaturgy. McGrail chose the adventures of the Chicago journalist Ben Hecht as depicted in his editorial column 1001 Afternoons in Chicago and autobiography A Child of the Century. Taking Hecht's journalistic dictum 'to remind the world that stories, not facts, are what make human life fascinating' (MCGRAIL 2017: 3), McGrail created an ambiguous fictional world that embraced both the idea of a 'document' and that of a 'play'. The piece acknowledged that frequently Hecht's stories were figments of his own artistic 
imagination, and as such in the performance a sense of theatrical wonder and amusement was evoked. On engaging with the parameters of the course, McGrail writes:

I find myself acting not only as the dramaturg, but [also as] the hypothetical director and scenic designer, as I must mentally create the staged circumstances to accompany a script. [...] In class we were always told that we must have the audience member in mind at all times, hence I related this experience to [...] being a 'dramaturg as first spectator'. [M]y project has taken what was already an established art form, literary art, and has adapted it to not only a theatrical form, but also a non-conventional form in which the spectator is asked to take on the lead role. (MCGRAIL 2017: 7-8)

Inspired by the chapter 'Chicago' from Hecht's autobiography, McGrail chose Chicago's Michigan Avenue as the primary site for his project. The itinerary of the audience walk that McGrail imagined was marked by Hecht's working day (from 6 a.m. to 3 p.m.) along with how Hecht's career evolved from ambulance-chaser towards that of an independent writer. Thus, the block 'Michigan Avenue between East Van Buren Street and East Congress Parkway - where there are still beautiful old buildings today, and a park with lake on the opposite side' has become the place for the dramaturgical exploration. 'The Fine Arts Building, the Chicago College of Performing Arts, and the Chicago Club' locations made up the performative settings of Ben Hecht and student's audience walks (MCGRAIL 2017: 9). An immersive audio experience with the audience moving through McGrail's fictional world was presented through Hecht's own eyes. Using an iPod, McGrail envisioned his spectators performing journalistic jobs for which Hecht was famous. He imagined using an iPod as a type of instruction manual which each spectactor would receive at the beginning of their experiential walk. Set on a shuffle pattern designed by McGrail, the iPod would give each spectator a series of commands, such as to take pictures, write notes, stop at certain scenes, observe people in action, and continue with their walk through the installation. The aesthetic dominant of this work was the atmosphere of the 1920s Chicago, created through the spatial dynamic of the walk that was to evoke or rather re-construct the city's rhythm. McGrail used the texts, the images, the associations, the music, and the films of Hecht's time to make this world viable.

\section{Conclusion}

Working with theatre theories of the Prague School means not only introducing students to its fundamental structural methodologies and categories of drama and performance analysis, but also teaching critical skills in reading theory as a historical document that in its analytical assumptions often reflects theatre and dramatic practices of its own time. Today's students are frequently compelled to question these statements and to propose their own theoretical models to examine the theatre practice they know or wish to create. Adding readings in more recent theatre theory which deal with 
similar issues of dramatic and theatre construction is also helpful, as these texts can help demonstrate the evolution of theoretical thought, hopefully revealing to learners how past and the modern ideas can complement each other. Such work becomes a lesson in theatre history as well. For example, Patrick Teed, another student in my 2017 class, proposed to construct a fictional world for a site-specific political cabaret he called 'Queens in Exile' based on the life and political activism of Sylvia Rivera, a founding member of the Gay Liberation Front and the Gay Activists Alliance of the US. This project presented a mix of a highly scripted counterfactual world and an improvisational political cabaret purposefully excessive in its execution (TEED 2017: 6-7). This project forced Teed to investigate the aesthetics of political theatre to locate strategies that might serve as 'an outlet for queering gender performatives and expressions' and help performers and spectators celebrate theatrical marginality and audience participation (TEED 2017: 8-9). The performance space as a mechanism of dramaturgical visualization of this stage/audience interaction and historical tension became indispensable in the execution of this work. In Teed's project, Zich's theatre stage turned into McAuley's performance space: a site-specific cabaret became the site for a political intervention with the audience and the performers interacting with each other and switching roles at will. This approach demonstrates one more time how the analytical toolbox developed by the Prague School Theatre theoreticians can be turned into an engine of creativity, specifically relevant in the pedagogical context of the North American institutions of higher education. As Teed reflected on his experience,

the methodological lessons gained through the developmental process [used in this class] were probably the greatest takeaway for me. I often struggle with executing my creative energies because I am so overwhelmed with possibilities and details that I lose sight of the world I am working in. By introducing me to Fuchs' [and other] articles, and restructuring it to be a creative tool, this course was able to uncover a creative methodology that kept me focused on the big picture of the world itself. This helped keep[ing] me on track of the work I was doing, and ultimately led to a quicker, more efficient developmental process than I am usually accustomed to. (TEED 2017: 12)

\section{Bibliography}

ARISTOTLE. 1987. Poetics. Transl. by Richard Janko (ed. and trans.). Indianapolis: Hackett Publishing Company, Inc., 1987.

BARRETT, Felix and Maxine DOYLE. 2009. In the Prae-sens of Body and Space - The (Syn)aesthetics of Site-Sympathetic Work. In Josephine Machon (ed.). (Syn)aesthetics: Redefining Visceral Performance. Basingstoke: Palgrave Macmillan, 2009: 89-100.

BOGART, Anne and Jackson GRAY. 2015. The Art of Collaboration: On Dramaturgy and Directing. In Magda Romanska (ed.). The Routledge Companion to Dramaturgy. New York: Routledge, 2015: 213-216. 
BRUŠÁK, Karel. 2016. Imaginary Action Space in Drama. In David Drozd, Tomáš Kačer and Don Sparling. Theatre Theory Reader: Prague School Writings. Prague: Karolinum Press, 2016: 303-319.

BOUKO, Catherine. 2015. Dramaturgy and the Immersive Theatre Experience. In Magda Romanska (ed.). The Routledge Companion to Dramaturgy. New York: Routledge, 2015: 459-461.

DE CERTEAU, Michel. 1985. Practices of Space. In Marshall Blonsky (ed.). In Signs. Baltimore: The John Hopkins University Press, 1985: 122-146.

DOLEŽEL, Lubomír. 1998. Possible Worlds of Fiction and History. New Literary History 29 (1998): 4: 785-809.

DRÁBEK, Pavel. 2016. Prague School Theory and its Contexts (Afterword). In David Drozd, Tomáš Kačer and Don Sparling. Theatre Theory Reader: Prague School Writings. Prague: Karolinum Press, 2016: 533-636.

DROZD, David and Tomáš KAČER. 2016. Introduction. In David Drozd, Tomáš Kačer and Don Sparling. Theatre Theory Reader: Prague School Writings. Prague: Karolinum Press, 2016: 13-27.

ECO, Umberto. 1987. Casablanca: Cult Movies and Intertextual Collage. In Umberto Eco. Travels in Hyper Reality: Essays. London: Picador, 1987: 197-268.

ELAM, Keir. 1980. The Semiotics of Theatre and Drama. New York: Routledge, 1980.

FIORINDI, Catherina. 2017. The Sophie Scholl Creative Project and Making of Counterfactual Worlds. Final Paper. THE 4123, Practice of Dramaturgy. University of Ottawa. 18. 04. 2017.

FISCHER-LICHTE, Erika. 2008. The Transformative Power of Performance: A New Aesthetics. Transl. by Saskya Iris Jai. London and New York: Routledge, 2008.

FOUCAULT, Michel. 1986. Of Other Spaces. Transl. by Jay Miskowiec. Diacritics 6 (1986): 1: 22-27.

FUCHS, Elinor. 2004. EF's Visit to a Small Planet: Some Questions to Ask a Play. Theatre 34 (2004): 2: 4-9.

GINGRICH, Derek. 2014. Unrecoverable Past and Uncertain Present: Speculative Drama's Fictional Worlds and Nonclassical Scientific Thought. MA thesis, University of Ottawa, 2014.

HURLEY, Erin. 2010. Theatre and Feeling. Houndmills: Palgrave, 2010.

HUTCHEON, Linda. 2006. A Theory of Adaptation. New York: Routledge, 2006.

JONAS, Susan S., Geoffrey S. PROEHL and Michael LUPU (eds.). 1996. Dramaturgy in American Theatre: A Source Book. Fort Worth: Harcourt, 1996.

MCAULEY, Gay. 1999. Space in Performance: Making Meaning in the Theatre. Ann Arbor: University of Michigan Press, 1999.

MCGRAIL, Colleen. 2017. Wonders To Be; Wonders That Were: A Practice of Dramaturgy. Final Paper. THE 4123, Practice of Dramaturgy. University of Ottawa. 18. 04. 2017.

MCKINNON, James. 2011. Creative Copying?: The Pedagogy of Adaptation. Canadian Theatre Review 147 (2011): 55-60.

MEERZON, Yana. 2015. Michael Chekhov's Theatre Theory and Pedagogy of Theatre Adaptation. Critical Stages 12 (2015). [accessed on 21.08. 2019]. Available online at: http://www.critical-stages.org/12/michael-chekhovs-theatre-theory-and-pedagogy-omef-theatre-adaptation/.

MUKAŘOVSKÝ, Jan. 2016. On the current state of the theory of theatre. In David Drozd, Tomáš Kačer and Don Sparling. Theatre Theory Reader: Prague School Writings. Prague: Karolinum Press, 2016: 59-75.

MURPHY, Vincent. 2013. Page to Stage: The Craft of Adaptation. Ann Arbor: The University of Michigan Press, 2013.

RUSH, David. 2005. Student Guide to Play Analysis. Carbondale: Southern Illinois University Press, 2005. 
SCHEIBE, Erin. 2014. Stages of Experience: Theatrical Connections between the Seven Stages of Experience and Historical Museums. Theatre Symposium 22 (2014): 99-109.

SCHOLL, Inge and Dorothee SÖLLE. 1983. The White Rose: Munich, 1942-1943. Middletown, CT: Wesleyan University Press, 1983.

TEED, Patrick. 2017. Dialectics of Performance/Reality: Investigating the Paradoxical Dramaturgies of Documentary Cabaret. Final Paper. THE 4123, Practice of Dramaturgy. University of Ottawa. April 18th, 2017.

PAVEL, Thomas G. 1989. Fictional Worlds. Cambridge and London: Harvard University Press, 1989.

TURNER, Cathy. 2014. Porous Dramaturgy and the Pedestrian. In Katalin Trencsényi and Bernadette Cochrane (eds.). New Dramaturgy: International Perspectives on Theory and Practice. London: Bloomsbury, 2014: 199-213.

VODIČKA, Felix. 1975. The Concretization of the Literary Work. In Peter Steiner (ed.). The Prague School Selected Writings 1929-1946. Austin: University of Texas Press, 1975: 103-133.

ZICH, Otakar. 2016. Principles of Theatrical Dramaturgy. In David Drozd, Tomáš Kačer and Don Sparling. Theatre Theory Reader: Prague School Writings. Prague: Karolinum Press, 2016: 34-59.

\section{Professor Yana Meerzon}

Department of Theatre, Faculty of Arts, University of Ottawa, 135 Séraphin-Marion, Ottawa K1N 6N5, Canada ymeerzon@uOttawa.ca

Yana Meerzon teaches for the Department of Theatre, University of Ottawa. Her research interests are in drama and performance theory, and theatre of migration and nationalisms. Her book publications include A Path of the Character: Michael Chekhov's Inspired Acting and Theatre Semiotics (2005) and Performing Exile - Performing Self: Drama, Theatre, Film (Palgrave 2012). She co-edited several collections, such as Performance, Exile and 'America', with Silvija Jestrovic (Palgrave, 2009); Adapting Chekhov: The Text and Its Mutations, with J. Douglas Clayton (Routledge, 2012/2015); History, Memory, Performance, with David Dean and Kathryn Prince (Palgrave, 2015); and Routledge Companion to Michael Chekhov, with Marie-Christine Autant-Mathieu (2015/2017). A special issue of the journal Modern Drama (Fall 2018), on which she worked on together with Dr. Katharina Pewny, focused on multilingualism and migration; with the $2^{\text {nd }}$ part of this project published by Routledge under the title Dramaturgy of Migration: Staging Multilingual Encounters in Contemporary Theatre (2019). With Meerzon's ongoing interest in the questions of theatre and immigration in Canada, she edited a special issue of Theatre Research in Canada (2015) and a two-volume project published by Playwrights Canada in June 2019. 